\title{
Anaesthetic Management for Caesarean Section Surgery in Two Pregnant Women with Severe Pulmonary Hypertension Due to Mitral Valve Stenosis
}

\author{
Mine Çelik ${ }^{1}$, Ayşenur Dostbil ${ }^{1}$, Hacı Ahmet Alici ${ }^{1}$, Serdar Sevimli ${ }^{2}$, Ayşenur Aksoy ${ }^{3}$, Ali Fuat Erdem¹, Hüsnü Kürşad \\ ${ }^{1}$ Department of Anesthesiology and Reanimation, Atatürk University Faculty of Medicine, Erzurum, Turkey \\ ${ }^{2}$ Department of Cardiology, Atatürk University Faculty of Medicine, Erzurum, Turkey \\ ${ }^{3}$ Department of Obstetric and Gynecology, Nenehatun Hospital, Erzurum, Turkey
}

\begin{abstract}
Background: Mitral stenosis is the most important and common cardiac complication seen during pregnancy. Conception is discouraged in cases where pulmonary hypertension develops during the course of mitral stenosis. Successful general and regional anaesthetic interventions have been reported in some cases of severe pulmonary hypertension.
\end{abstract}

Case Reports: We present our experiences with anaesthetic management in two pregnant patients with pulmonary hypertension due to mitral valve stenosis.

Conclusion: We preferred to continue spinal anaesthesia because gradually increasing the local anaesthetic dose during the procedure may minimise probable undesirable haemodynamic changes, such as hypotension and tachycardia.

Key Words: Mitral Stenosis, pulmonary hypertension, caesarean section, regional anaesthesia

Received: 24.12 .2012

Accepted: 25.07 .2013

\section{Introduction}

Pulmonary arterial hypertension (PAH) is defined as a mean pulmonary artery pressure greater than $25 \mathrm{mmHg}$ at rest and greater than $30 \mathrm{mmHg}$ with exercise (1). Maternal mortality rises up to $15 \%$ in mitral stenosis cases complicated with pulmonary hypertension (2). Pregnancy-induced physiological changes also result in a deterioration of existing cardiac pathology. The European and American Cardiology Associations have recommended that patients with $\mathrm{PAH}$ are not encouraged to get pregnant and any pregnancy must be terminated (3). The implementation of general anaesthesia (4), combined spino-epidural anaesthesia (5), epidural anaesthesia (6), and continuous spinal anaesthesia (7) in pregnant women with $\mathrm{PAH}$ has been reported in the literature. We present two cases of PAH due to mitral valve disease in pregnant patients.

\section{Case Reports}

\section{Case 1}

The patient underwent an emergency Caesarean section (CS) operation under general anaesthesia for the first CS due to the development of foetal distress. Continuous spinal anaesthesia was planned during the operation for the second CS. The patient was transferred to the operation room. The central venous pressure and the arterial pressure were moni- tored via central venous catheterisation through the internal jugular vein and radial artery catheterisation under local anaesthesia, respectively. Standard monitoring included evaluation of the peripheral oxygen saturation and electrocardiography. The central venous pressure, heart rate, and arterial blood pressure were $15 \mathrm{mmHg}, 84$ beats/min, and 120/70 $\mathrm{mmHg}$, respectively. Following administration of subcutaneous anaesthesia in the sitting position under aseptic conditions, a spinal catheter (B. Braun ${ }^{\circledR}$, Melsungen, Germany) was inserted through the intervertebral space between the L4-L5 vertebrae. Then, $1 \mathrm{~mL} 0.5 \%$ plain bupivacaine was injected through the catheter. The sensorineural block level was found to be at T10. After administration of a second dose of 0.5 $\mathrm{mL} 0.5 \%$ plain bupivacaine, the sensorineural block level was raised to T6, followed by commencement of the operation. The operation comprised a Caesarean section and tube ligation. The patient complained of pain following extraction of the baby, and $0.2 \mathrm{~mL} 0.5 \%$ plain bupivacaine was re-administered, raising the sensorineural block level to T4. The operation was not complicated by bradycardia or hypotension. The patient was administered a total of $700 \mathrm{~mL}$ of fluid (lactated Ringer's solution) during the operation. Prior to transferring the patient to the intensive care unit, the spinal catheter was removed. Postoperative pain management was achieved intravenously by a patient-controlled analgesia (PCA) pump (fentanyl $20 \mu \mathrm{g} / \mathrm{h}$ with a bolus dose of $20 \mu \mathrm{g}$ and a loading dose of $30 \mu \mathrm{g}$ ). The patient had been taking low-molecular-

These cases were presented at the $11^{\text {th }}$ National Regional Anesthesia Congress, 25-28 November 2010, Istanbul, Turkey.

Address for Correspondence: Dr. Mine Çelik, Department of Anesthesiology and Reanimation, Atatürk University Faculty of Medicine, Erzurum, Turkey Phone: +90 4423447929 e-mail: mine.celik74@gmail.com 
Table 1. Demographic properties, preoperative condition, and outcome of patients

\begin{tabular}{|c|c|c|c|}
\hline & \multicolumn{2}{|l|}{ Case 1} & \multirow[t]{2}{*}{ Case 2} \\
\hline & $1^{\text {st }} \mathrm{CS}$ & $2^{\text {nd }} \mathrm{CS}$ & \\
\hline Age (years) & 24 & 31 & 30 \\
\hline Gestation week & 35 & 38 & 37 \\
\hline History & $\begin{array}{l}\text { Open mitral commissurotomy } \\
\text { at } 10 \text { years of age }\end{array}$ & $\begin{array}{l}\text { Open mitral commissurotomy } \\
\text { at } 10 \text { years of age }\end{array}$ & $\begin{array}{l}\text { Balloon valvuloplasty at } 25 \text { years } \\
\text { of age }\end{array}$ \\
\hline $\begin{array}{l}\text { Physical } \\
\text { examination }\end{array}$ & $\begin{array}{l}\text { Ortopnoea, dyspnoea, } \\
\text { peripheral edemas, S3 Gallop }\end{array}$ & $\begin{array}{l}\text { Peripheral edemas }(+3) \\
\text { dyspnoea, S3 gallop rhythm }\end{array}$ & $\begin{array}{l}\text { Severe orthopnoea, dyspnoea, } \\
\text { peripheral edemas }(+3)\end{array}$ \\
\hline $\mathrm{ECHO}$ findings & $\begin{array}{l}\text { Moderate degree of mitral } \\
\text { stenosis (mitral valve area= } \\
1.2 \mathrm{~cm}^{2} \text { ), severe tricuspid } \\
\text { regurgitation, } \\
\text { PAP }=45 \mathrm{mmHg}\end{array}$ & $\begin{array}{l}\text { Severe mitral stenosis (mitral } \\
\text { valve area }=0.9 \mathrm{~cm}^{2} \text { ), } \\
\text { severe tricuspid regurgitation, } \\
P A P=50 \mathrm{mmHg}\end{array}$ & $\begin{array}{l}\text { Mitral valve area }=1.9 \mathrm{~cm}^{2}(1.2 \\
\mathrm{cm}^{2} \text { before the balloon } \\
\text { valvuloplasty }) \\
\mathrm{PAP}=60 \mathrm{mmHg}\end{array}$ \\
\hline NYHA class & Class 3 & Class 4 & Class 4 \\
\hline Medication & $\begin{array}{l}\text { Furosemide } 40 \text { mg twice daily, } \\
\text { metoprolol succinate } 100 \mathrm{mg} \\
\text { once daily }\end{array}$ & $\begin{array}{l}\text { Metoprolol succinate } 50 \mathrm{mg} \\
\text { and furosemide } 40 \mathrm{mg} \text { twice } \\
\text { daily }\end{array}$ & $\begin{array}{l}\text { Metoprolol succinate } 50 \text { mg, } \\
\text { furosemide } 40 \mathrm{mg} \text { twice daily. }\end{array}$ \\
\hline $\begin{array}{l}\text { Cause of } \\
\text { Caesarean } \\
\text { delivery }\end{array}$ & $\begin{array}{l}\text { Development of foetal distress. } \\
\text { Performed emergent } \\
\text { Caesarean delivery }\end{array}$ & Previous Caesarean section & $\begin{array}{l}\text { The cardiologist decided for } \\
\text { termination of pregnancy due to } \\
\text { patient's clinical status (pulmonary } \\
\text { edema) }\end{array}$ \\
\hline $\begin{array}{l}\text { Type of } \\
\text { anaesthesia }\end{array}$ & General anaesthesia & Continuous spinal anaesthesia & Continuous spinal anaesthesia \\
\hline Discharge time & 7 days & 3 days & 5 days \\
\hline Outcome & $\begin{array}{l}\text { Mother and baby are healthy. } \\
\text { Pregnancy was banned for } \\
\text { patient }\end{array}$ & $\begin{array}{l}\text { Mother and baby are healthy. } \\
\text { Recommendations about diuretic } \\
\text { usage and subsequent outpatient } \\
\text { cardiology visits. Two years later, } \\
\text { she underwent mitral valvuloplasty }\end{array}$ & $\begin{array}{l}\text { Mother and baby are healthy. } \\
\text { Recommendations about diuretic } \\
\text { usage and subsequent outpatient } \\
\text { cardiology visits. Pregnancy was } \\
\text { banned for patient }\end{array}$ \\
\hline
\end{tabular}

weight heparin treatment throughout the pregnancy period. Following the removal of the spinal catheter, the same antithrombotic therapy was reinstituted. The patient was closely monitored by a cardiologist for 24 hours in the intensive care unit.

\section{Case 2}

Preanaesthetic monitoring was performed as Case 1. The central venous pressure, heart rate, and arterial blood pressure were $20 \mathrm{mmHg}$, 85 beats/min, and 110/60 $\mathrm{mmHg}$, respectively. Continuous spinal anaesthesia was administered through the intervertebral space between the L4-L5 vertebrae. Then, $1 \mathrm{~mL} 0.5 \%$ of plain bupivacaine was administered to the patient in a sitting position, following which she was returned to a supine position. An additional dose of $0.5 \mathrm{~mL}$ $0.5 \%$ bupivacaine was re-injected after checking that the sensorineural level was at T7. The operation was commenced when the sensorineural level was raised to T4. The arterial blood pressure dropped by $20 \%$, and $15 \mathrm{mg}$ of ephedrine was administered. No bradycardia was observed. The patient was administered a total of $500 \mathrm{~mL}$ fluid $(0.09 \% \mathrm{NaCl}$ solution) during the operation. Following the removal of the spinal catheter, postoperative analgesia was achieved intravenously with a PCA pump (fentanyl $20 \mu \mathrm{g} / \mathrm{h}$ with a bolus dose of $20 \mu \mathrm{g}$ and a loading dose of $30 \mu \mathrm{g}$ ). Low-molecular-weight heparin, which had been suspended 24 hours before the operation, was reinstituted.

\section{Discussion}

The intravascular volume increases by $50 \%$ during pregnancy. Consequently, the filling pressure of the left atrial and pulmonary veins rises. Moreover, the increased heart rate reduces the left ventricular filling time. These physiological changes lead to serious haemodynamic problems in patients with mitral stenosis (2).

There is no currently no consensus on the choice of anaesthetic management, which depends on the severity of the disease. A review of case presentations published between 1997 and 2007 revealed a higher rate of maternal mortality 
in patients undergoing Caesarean section surgery under general anaesthesia because volatile agents utilised in general anaesthesia may depress cardiac contractility, positive pressure ventilation may increase pulmonary resistance, and laryngoscopy and orotracheal intubation may lead to elevation of pulmonary arterial blood pressure (8).

In the studies conducted, general anaesthesia was implemented in emergency Caesarean sections, but neuroaxial block was preferred in elective cases (4-6). However, we used neuroaxial anaesthesia in our emergency case.

Kocum et al. (2) described a Caesarean section with mitral stenosis complicated with pulmonary hypertension that they successfully managed with epidural anaesthesia. They have suggested that close haemodynamic monitoring and careful titration of epidural anaesthesia are essential to prevent an extreme decrease in cardiac preload.

A previous study reported that haemodynamic changes returned to preconception levels within 15 days postpartum and that maternal mortality occurred most frequently in the first few days following the delivery (9). It also emphasised the need for meticulous fluid management and monitoring before and after the delivery in patients with pulmonary hypertension, in addition to the continuation of vasodilator therapy and the implementation of anticoagulation therapy in the early postpartum period in patients with pulmonary hypertension.

Gandhimathi et al. (7) administered continuous spinal anaesthesia during a Caesarean section in a patient with pulmonary hypertension who gave birth to twin babies. They reported successful anaesthetic management, as well as adequate surgical comfort and minimal variation in haemodynamic parameters. Dresner et al. (10) reported the use of continuous spinal anaesthesia in 34 Caesarean sections in patients with complex cardiac disease. They stated that they achieved perfect haemodynamic stability by effectively titrating the local anaesthetic agents. Craig et al. (11) underlined in their review that continuous spinal anaesthesia used during Caesarean section surgeries in patients with significant cardiac disease could allow for implementation of local anaesthetics in divided doses, thereby gaining time in order to compensate for the development of unwanted side-effects.

In conclusion, epidural, spinal, or continuous spinal anaesthesia can be performed and monitored during Caesarean sections in patients with mitral stenosis complicated with $\mathrm{PAH}$. We preferred continue spinal anaesthesia because gradually increasing the local anaesthetic dose during the procedure may minimise probable undesirable haemodynamic changes, such as hypotension and tachycardia. Cautious postpartum fluid management and close monitoring are vital during the early postpartum period.
Ethics Committee Approval: Ethics committee approval was received for this study from the Atatürk University Faculty of Medicine Ethics Committee (2013/6 - 46)

Informed Consent: Written informed consent was obtained from the participants of this study.

Peer-review: Externally peer-reviewed.

Author contributions: Concept - M.Ç., H.A.A., A.A.; Design - A.D., S.S.; Supervision - H.A.A., A.F.E..; Resource - A.A., S.S.; Materials S.S., A.F.E., M.Ç.; Data Collection\&/or Processing - M.Ç., A.D.; Analysis\&/or Interpretation - H.K., A.D.; Literature Search - M.Ç., H.A.A., A.D.; Writing - M.Ç., A.F.E., H.K.; Critical Reviews - H.A.A., H.K.

Conflict of Interest: No conflict of interest was declared by the authors.

Financial Disclosure: The authors declared that this study received no financial support.

\section{References}

1. Madden BP. Pulmonary hypertension and pregnancy. Int J Obstet Anesth 2009;18:156-64. [CrossRef]

2. Kocum A, Sener M, Calıskan E, Izmirli H, Tarım E, Kocum T, et al. Epidural anesthesia for cesarean section in a patient with severe mitral stenosis and pulmonary hypertension. J Cardiothorac Vasc Anesth 2010;24:1022-3. [CrossRef]

3. Task Force on the Management of Cardiovascular Diseases During Pregnancy of the European Society of Cardiology. Expert consensus document on management of cardiovascular diseases during pregnancy. Eur Heart J 2003;24:761-81. [CrossRef]

4. Paternoster DM, Pascoli I, Parotto M, Cester M, Nanhornguè $K$, Merati $E$, et al. Pulmonary hypertensin during pregnancy:management of two cases. Arch Gynecol Obstet 2010;281:431-4. [CrossRef]

5. Duggans AB, Katz SG. Combined spinal and epidural anesthesia for cesarean section in a parurient with severe primary pulmonary arterial hypertension? Anaesth Intensive Care 2003;31:565-9.

6. Breen TW, Janzen JA. Pulmonary hypertension and cardiomyopaty: anaesthetic management for caesarean section. Can J Anaesth 1991;38:895-9. [CrossRef]

7. Gandhimathi K, Atkinon S, Gibson FM. Pulmonary hypertension complicating twin pregnancy:continuous spinal anaesthesia for caesarean section. Int J Obstet Anesth 2002;11:301-5. [CrossRef]

8. Bedard E, Dimopoulus K, Gatzoulis MA. Has there been any progress made on pregnancy outcomes among women with pulmonary arterial hypertension? Eur Heart J 2009;30:256-65. [CrossRef]

9. Higton AM, Whale C, Musk M, Gabbay E. Pulmonary hypertension in pregnancy:two cases and review of te literature. Int Med J 2009;39:766-70. [CrossRef]

10. Dresner $M$, Pinder A. Anaesthesia for caesarean section in women with complex cardiac disease: 34 cases using the Braun Spinocath spinal catheter. Int J Obstet Anest 2009;18:131-6. [CrossRef]

11. Palmer CM. Continuous spinal anesthesia and analgesia in obstetrics. Anesth Analg 2010;6:1476-9. [CrossRef] 